\title{
Implementation of human resource management functions in selected small manufacturing companies in Ga-Rankuwa industrial area, Gauteng, South Africa
}

\begin{tabular}{|c|c|}
\hline \multicolumn{2}{|c|}{$\begin{array}{l}\text { Authors: } \\
\text { Ingrid L. Potgieter }{ }^{1} \text { (D) } \\
\text { Segopotse E. Mokomane }{ }^{2}\end{array}$} \\
\hline \multicolumn{2}{|c|}{$\begin{array}{l}\text { Affiliations: } \\
\text { 'Department of Human } \\
\text { Resource Management, } \\
\text { College of Economic and } \\
\text { Management Sciences, } \\
\text { University of South Africa, } \\
\text { Pretoria, South Africa }\end{array}$} \\
\hline \multicolumn{2}{|c|}{$\begin{array}{l}{ }^{2} \text { Human Resources Staffing } \\
\text { and Client Services, Human } \\
\text { Resources (Support } \\
\text { Department), University } \\
\text { of South Africa, Pretoria, } \\
\text { South Africa }\end{array}$} \\
\hline \multicolumn{2}{|c|}{$\begin{array}{l}\text { Corresponding author: } \\
\text { Ingrid Potgieter, } \\
\text { visseil@unisa.ac.za }\end{array}$} \\
\hline \multicolumn{2}{|c|}{$\begin{array}{l}\text { Dates: } \\
\text { Received: } 30 \text { Sept. } 2019 \\
\text { Accepted: } 16 \text { June } 2020 \\
\text { Published: } 31 \text { Aug. } 2020\end{array}$} \\
\hline \multicolumn{2}{|c|}{$\begin{array}{l}\text { How to cite this article: } \\
\text { Potgieter, I.L., \& } \\
\text { Mokomane, S.E. (2020). } \\
\text { Implementation of human } \\
\text { resource management } \\
\text { functions in selected small } \\
\text { manufacturing companies in } \\
\text { Ga-Rankuwa industrial area, } \\
\text { Gauteng, South Africa. SA } \\
\text { Journal of Human Resource } \\
\text { Management/SA Tydskrif vir } \\
\text { Menslikehulpbronbestuur, } \\
\text { 18(0), a1282. https://doi.org/ } \\
\text { 10.4102/sajhrm.v18i0.1282 }\end{array}$} \\
\hline \multicolumn{2}{|c|}{$\begin{array}{l}\text { Copyright: } \\
\text { (C) 2020. The Authors. } \\
\text { Licensee: AOSIS. This } \\
\text { work is licensed under } \\
\text { the Creative Commons } \\
\text { Attribution License. }\end{array}$} \\
\hline \multicolumn{2}{|l|}{ Read online: } \\
\hline 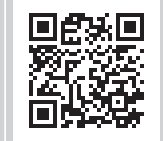 & $\begin{array}{l}\text { Scan this QR } \\
\text { code with your } \\
\text { smart phone or } \\
\text { mobile device } \\
\text { to read online. }\end{array}$ \\
\hline
\end{tabular}

Orientation: Human resource management (HRM) is a fundamental element in the success of any organisation. Research on HRM functions in medium and large organisations has been given much attention. However, few research studies have been conducted in assessing the importance and implementation of HRM functions in small companies.

Research purpose: The objective of this study was to investigate the implementation of HRM functions and its perceived importance in small manufacturing companies (SMC), as well as the limitations or barriers to effective HRM implementation in SMCs.

The motivation for the study: Human resource management functions play a strategic role in any organisation. Literature studies indicate that relatively little is known about HRM functions in small businesses. This research aimed to contribute to the knowledge of HRM and enhance the understanding and importance of the HRM functions in SMCs.

Research approach/design and method: A qualitative research design was followed. A convenience sampling technique was used with eight participants. Data were collected by means of semi-structured interviews.

Main findings: The HRM functions of recruitment and orientation, general labour relations, human resource information systems (HRIS), performance management, training and development, and remuneration and benefit were informally implemented and acknowledged as crucial in SMCs. The study further found that a limited budget, lack of resources and capacity, inadequate systems, ineffective employment relationships, lack of knowledge and understanding of HRM functions and business instability negatively affect SMCs to implement all HRM functions within the business and therefore negatively influence the performance of the company.

Practical/managerial implications: All managers/owners and employees are aware of all the HRM functions that could enhance the performance and success of their organisation.

Contribution/value-add: The study findings will assist SMCs to implement and understand the importance of HRM functions as well as the barriers to effective implementation of HRM functions.

Keywords: human resource management; HRM functions; small manufacturing companies; small businesses; general labour relations; training and development; performance management.

\section{Introduction}

The research literature shows that several studies have been conducted in medium and large companies to assess the effectiveness of human resource management (HRM) functions. Most of the medium and large companies have developed effective human resource (HR) strategies to manage their employees (Bartram, 2005; Chand \& Katou, 2007; Cho, Woods, Jang, \& Erdem, 2006; Kotter, 2014; Malhotra \& Temponi, 2010; Ogunyomi \& Bruning, 2016; Olson \& Staley, 2012; Pajo, Coetzer, \& Guenole, 2010; Psychogios, Szamosi, Prouska, \& Brewster, 2016). Small companies, however, have not been given much attention in this regard.

Several definitions of small companies or small manufacturing enterprises (or small manufacturing company [SMC]) are found in the literature. According to the Australian Fair Work Act (2009), small businesses employ less than 15 employees. The European Union classifies a business as small if it employs fewer than 50 employees. Totka (2013) defined a small business as an organisation where fewer than 500 employees are employed. According to Prajapati (2018), financial turnover and capital are the main characteristics to classify a company as a small 
business. Most definitions, however, seem to agree that a small business is defined by either the number of employees employed in the organisation or by its annual turnover.

Krishnan and Scullion (2017) noted that SMCs play an important role in the economy of any country. Small businesses are confronted with challenges such as insufficient managerial skills, lack of trained staff, poor financial management, limited budget and technology, all of which impact negatively the business performance and success (Karadag, 2015; Mokomane, 2018). Mokomane (2018) confirmed that although HR practices in SMCs are done informally, a small business still encounters several challenges to the successful implementation of HRM functions. Some of these challenges include limited budgets, lack of resources and capacity, inadequate systems, poor relationships between employer and employees and lack of HR knowledge and business instability.

This article aims to broaden research on the implementation of HRM functions and its perceived importance in SMCs, as well as the limitations or barriers to effective HRM implementation in selected SMCs in the Ga-Rankuwa industrial area of the Gauteng province. The findings from the research may contribute to the field of HRM. More specifically, this article contributes to the knowledge of human resources in terms of identifying which functions are implemented in SMCs and how it relates to the perceived importance of the function. On a theoretical level, the research findings may be useful for future research, contribute to the knowledge of HRM and positively enhance the understanding and importance of the HRM functions in a small organisation. On a practical level, the research can be used by SMCs to create awareness in terms of which functions are indeed crucial for the success of an organisation. In addition, recognition will be created in terms of the barriers to successful implementation of HRM. Organisations can use this knowledge to implement the functions deemed necessary as well as to design strategies to reduce the identified barriers.

\section{Problem statement}

Global changes in the manufacturing setting directly influence the competitiveness of SMCs in South Africa. For an SMC to be competitive, it should have policies and procedures to guide it to remain and maintain a competitive edge. In view of the above, this article aimed to investigate the implementation of HRM functions as guidance to competitiveness and its perceived importance for SMCs, as well as the limitations and barriers to effective HRM implementation in SMCs. The findings will address the problem of the limited information available with regard to HRM functions within SMCs.

\section{Research questions}

This article addressed the following research questions:

- Which HRM functions are most commonly implemented in SMCs?

- What is the perceived importance of the HRM functions implemented in SMCs?
- What are the perceived limitations/barriers to effective HRM implementation in SMCs?

- What recommendations can be made to improve HRM functions?

\section{Literature review}

Human resource management is a strategic approach to the effective management of employees within an organisation to gain and enhance competitive advantage and successful performance. Several HRM functions were found in the literature, which can be used to manage employees successfully within an organisation. Ogunyomi and Bruning (2016:66) indicated that the core HRM functions include (1) planning and recruitment, selection and induction; (2) performance management; (3) learning and development and (4) recognition and reward'. Akpan (2011) added employee well-being to the core HRM functions. Haslinda (2009) categorised HRM functions into recruitment and selection; compensation and benefits, labour and industrial relations; and safety and health management, training and development, performance appraisals management, career planning and development, and change management. According to Psychogios et al. (2016), HRM in SMEs has mainly been studied in Western countries or large economies (such as the East). It is therefore important to take typical HRM functions within the South African context into consideration.

For this study, the HRM model of the South African Board for People Practices (SABPP) was adopted. The SABPP HRM model outlines the minimum set of HR practices that small, medium and large companies should apply to successfully and efficiently manage their employees. The SABPP HR System Standards Model consists of 13 HRM functions (see Table 1).

Human resource management is a vital strategic partner in the business environment, as it ensures that the business has qualified employees to conduct daily business (Jacobson \& Sowa, 2015; Krishnan \& Scullion, 2017). The success of a business highly depends on the management of its employees and a proper established structure within the business (Sheehan, 2014). The importance of implementing HRM functions in SMCs is considered valuable and contributes to the organisational goals (Ogunyomi \& Bruning, 2016; $\mathrm{Wu}, 2014)$. If HRM functions are not implemented, the turnover rate of employees will increase and productivity will decrease (Henning, 2019; Shen, Chanda, D'Netto, \& Monga, 2009). An organisation may have trouble to resolve conflict owing to the lack of labour relations policies and procedures to handle employee relations matters (Caldwell, Truong, Linh, \& Tuan, 2011). Most small companies fail to apply HRM functions and, as a result, individuals are appointed in positions where they do not possess the relevant skills and knowledge (Guest, 2011). Employees in most SMCs are not being trained or developed to improve on their current capacity; employees are unfairly remunerated, organisations typically encounter 
TABLE 1: Human resource management functions as categorised by the South African Board for People Practices.

HRM function
Strategic human resource
management
Description

The process of ensuring that HRM functions of an organisation are identified, and HR plans are effectively
implemented in line with the business strategy to ensure that the long-term goals of the organisation are management achieved.

Recruitment

The process of identifying the skills demanded by the organisation and establishing the hiring cost implications before embarking on the recruitment process. Recruitment can either be done externally or internally to attract and appoint an applicant on a temporary, fixed-term or permanent basis owing to the internally to attract and appoint an applica
operational needs of the organisation.

Selection The process of screening and selecting the candidates whose qualification, experience, skills, and knowledge Chan and Kuok (2011), Kumari (2012) match the requirements of the advertised position. The selection process utilises relevant HR tools and techniques to find a suitable candidate to fill the vacant post.

Orientation

The process whereby the organisation provides new employees with a formal introduction to the existing employees, employees are introduced to the organisation's culture, its clients and procedures and policies of the organisation and to ensure that employees understand what is expected from them. Orientation is used as an ideal awareness and communication tool to provide information about the business operations to the new employees.

Training and development Training is the process of assisting employees to gain the required skills to effectively perform the duties Grossman and Salas (2011), Karakas and and increase their present knowledge. Training provision plays a crucial role as it serves as a form of motivation and inspiration mechanism for employees to be committed to the organisation. Development involves the process of empowering employees to acquire needed skills, experience and knowledge to promote growth within the organisation. Human resource management development focuses on strategic HRM that is human capital contributions, strategic capabilities and an organisation's competitive performance to be more responsive to internal and external changes, which might have an impact on the business.

Talent management The process of attracting and selecting talented individuals internally and externally to achieve the objectives of the organisation. Talent management is a succession planning tool that is used to identify and develop people for a particular position to retain and reward their talent within the organisation.

Labour relations The process of managing unionised employment situations to resolve conflicts that may arise in the business Baird and Williamson (2010), Batt and environment and to promote healthy relationships amongst employees and employers; labour relations thus Banerjee (2012) involve the relationship between employees and employers within the business environment. This includes initiation, development and implementation of human resource policies, which are aligned with the South African labour legislation and in consultation with and involvement of the bargaining council, where there are representatives for employees.

Remuneration and

benefits

Remuneration involves the process whereby employers reward employees in the form of salary or wages for the completed job/task as per the contract of employment. Benefits refer to the compensation paid by an
employer to its employees, which includes medical aid, pension funds, unemployment insurance and group life insurance, injury on duty and relocation benefits. The correct standard for the administration of employees' remuneration and benefits should be applied to ensure that the administration is aligned with the Basic Conditions of Employment Act No. 75 of 1997.

Organisational The process of creating continuous improvement within the organisation by ensuring that organisational development align with the external and internal changes in the busing onvironment. Organisational development is the process of planning and designing the structure of the organisation by growing the capacity within the company to achieve the objectives of the organisation.

Performance management

Performance management is the systematic approach of measuring the performance of employees to evaluate whether the tasks are accomplished as indicated in their job description. Performance management involves the process of assessing both individuals and group performance. Performance management is done to monitor individual and group performance to assist employers in pinpointing which individuals or groups need further assistance or training to meet the organisational and individual objectives.

Human resource Human resource information system is the computer-based system used by human resource practitioners information systems (HRIS) to enter data into the system: to create employment records, capture and update employees' personal information and upload vacant positions for online applications.

Manisaligil (2012), Nel (2001), Tomé (2011)

Kehoe and Wright (2013), Lengnick-Hall, Lengnick-Hall and Rigsbee (2013) Schalk, Timmerman and Van den Heuvel (2013)

Keeling, McGoldrick and Sadhu (2013), Nielsen (2015)

Dimba and Rugimbana (2013), Schultz (2001)

\author{
and Bussi
}

Du Plessis and Fouché (2006), Kaur

(2013), Przytuła (2013) Ceylan (2013), Turner, Swart and Maylor
(2013)

Louw-Potgieter (2012), Yadav and

Dabhade (2013)

Benedict (2013), Dulebohnn and Johnson (2013)

Measuring HR success Measuring human resource success is the process of determining the importance and effectiveness of HRM Bani, Bani, Pourbagher, Taghavi and functions to assess its contribution towards organisational goals. Measuring human resource success focuses Mansourian (2014), Davidson, Timo and on measuring the budgets of human resource departments, such as assessing training expenses, advertising Wang (2010) on measuring the budgets of human resource departme
and hiring costs as well as talent management costs.

HRIS, Human resource information systems; HRM, human resource management; HR, human resource.

several grievances and, ultimately, it affects negatively the operations and success of the organisation (Frick, Malo, Martinez, \& Schneider, 2012).

Previous research (Krishnan \& Scullion, 2017; Nolan \& Garavan, 2016) has revealed several reasons for the lack of implementation of HRM functions in SMCs. Some of the reasons identified by these authors include (1) a lack of guidelines or procedures to assist employees in understanding and practising HRM functions; (2) lack of HRM professionals to help organisations to implement the functions effectively; (3) insufficient managerial skills; (4) lack of trained staff; (5) poor financial management; (6) a limited budget to implement functions; and (7) lack of experience, skills and competence to perform and manage HRM functions. Although it is important, it is not always possible for all SMCs to implement all the HRM functions. It is however important to recognise which functions are vital for the organisational success.

\section{Aim and purpose of the study}

Ineffective implementation of HRM functions in small businesses can lead to lower productivity and a reduced competitive advantage (Sikora \& Ferris, 2014). This study therefore aimed to investigate the implementation of HRM functions and its perceived importance in SMCs, as well as the limitations and barriers to effective HRM implementation in SMCs.

\section{Research method and design Research approach}

This study employed a qualitative research design with a descriptive research approach to determine the perceived importance of HRM functions implemented in SMCs as well as limitations or barriers to effective HRM implementation in SMCs. The researcher thus aimed to describe the precise lived experiences of the 
individuals without an assumption about the phenomenon under study (Oliver, 2012).

\section{Research strategy}

In this transcendental or descriptive phenomenological study, employees employed in SMCs within the Ga-Rankuwa industrial area were interviewed. Phenomenologists focused on describing what all participants have in common as they experience a phenomenon (Giorgi, 2010).

\section{Research setting}

The research setting refers to the physical environment in which the researcher conducts the interview (Mannay, 2010). The research was conducted amongst SMCs within the Ga-Rankuwa industrial area. The interviews were held at the participants' workplace in a setting provided by the participants at an appropriate site of convenience. The research setting and physical environment are vital as these aspects can influence the outcome of the research (King \& Horrocks, 2010; Terre Blanche, Durrheim, \& Painter, 2006). Therefore, the researcher ensured that the interview setting was comfortable, allowed for privacy and that it was a quiet surrounding during the interviews.

\section{Entree and establishing researcher roles}

The researcher plays different roles in the research. In this study, access to the research setting was undertaken by obtaining permission from the owners or managers of the relevant SMCs within the Ga-Rankuwa industrial area. The researcher planned and conducted the interviews at the participants' workplace. The researcher first explained the research process and obtained informed consent from the participants before commencing the interview.

\section{Participants and sampling}

De Queiroz (2007) defined delimitations as the determination of the boundaries and specific numbers of the cluster from the empirical study. This research only focused on SMCs at Ga-Rankuwa industrial area (Gauteng province). A convenience sampling technique was used to select the SMCs in the area. Therefore, SMCs that were accessible to use and willing to participate were selected for the study. The study excluded other small companies and SMCs from other provinces and other areas within Gauteng province. This study, in particular, used a qualitative method approach to investigate the implementation of HRM functions and its perceived importance, as well as the limitations or barriers to HRM functions in SMCs. The participants in this research were managers, supervisors, HR practitioners or officers and employees involved in HR administration. The sample was a minimum of eight participants within different SMCs or until data saturation was reached.
TABLE 2: Interview questions.

\begin{tabular}{|c|c|}
\hline Question & The rationale for including this question \\
\hline $\begin{array}{l}\text { Which HRM functions are most } \\
\text { commonly implemented within } \\
\text { SMCs? }\end{array}$ & $\begin{array}{l}\text { This question helped to identify HRM functions, } \\
\text { which are most commonly implemented within } \\
\text { SMCs. }\end{array}$ \\
\hline $\begin{array}{l}\text { What is the perceived importance } \\
\text { of the HRM functions implemented } \\
\text { in SMCs? }\end{array}$ & $\begin{array}{l}\text { This question helped to identify the perceived } \\
\text { importance of the HRM functions implemented } \\
\text { in SMCs. }\end{array}$ \\
\hline $\begin{array}{l}\text { What are the perceived limitations } \\
\text { or barriers to effective HRM } \\
\text { implementation in SMCs? }\end{array}$ & $\begin{array}{l}\text { This question helped to identify the perceived } \\
\text { limitations or barriers to effective HRM } \\
\text { implementation in SMCs. }\end{array}$ \\
\hline $\begin{array}{l}\text { What recommendations can be } \\
\text { formulated for improving HRM } \\
\text { practices? }\end{array}$ & $\begin{array}{l}\text { This question helped to propose } \\
\text { recommendations to improve the } \\
\text { implementation of HRM functions. }\end{array}$ \\
\hline
\end{tabular}

HRM, Human resource management; SMCs, small manufacturing companies.

\section{Data collection methods}

Data collection is the process of identifying the data collection methods to gather and measure information from a range of sources to obtain appropriate outcomes (Brod, Tesler, \& Christensen, 2009). A qualitative data collection method was used in this study. Semi-structured interview questions were used as a data collection method concerning the perceptions of the implementation, perceived importance and limitations or barriers to HRM functions in SMCs. Semi-structured interviews were conducted with the following four open-ended questions (see Table 2).

\section{Recording of data}

Interviews were conducted in English, and all the participants were fluent in English. All the meetings were audio-recorded, transcribed verbatim and then checked by the researcher. The interviews were audio-recorded to ensure correctness, truth and quality of the data. Recording of the interview ensured that the researcher correctly captured the qualitative data (Tuffrey-Wijne \& Butler, 2009). The transcripts were used in the data analysis process. Both the audio recordings and transcripts were kept in a safe place to maintain confidentiality.

\section{Data analyses}

Data analysis is a process in which the data are broken down into smaller meaningful pieces to interpret and conceptualise it (Bailey, 2008). The researcher ensured that preconceptions do not twist the meaning of the data discovered (Lukka \& Modell, 2010). A categorising technique was used to analyse the data in this study (Vaismoradi, Turunen, \& Bondas, 2013). Accordingly, similar data were grouped and conceptualised before axial coding was employed. Open coding is applicable to analyse qualitative data by naming and categorising or grouping similar data, whereas axial coding links various categorised data obtained from open coding to relate to each other. Most importantly, the analysis of the qualitative research methodology using the phenomenological approach allowed the researcher to discover and interpret participants' lived experiences (Sloan \& Bowe, 2014). 


\section{Research quality assurance}

Peredaryenko and Krauss (2013) noted that the main instrument in qualitative research is the researcher because the researcher observes, writes notes, speaks to participants, interprets and makes sense of the phenomenon under study. The researcher consulted theoretical literature applicable to the research topic and used a triangulation strategy to collect and compare multiple data sources to search for common themes to support the theory. A qualitative approach using semi-structured interviews was used to control bias and provide valid and conclusive evidence. Prior to the interviews, the researcher read a prepared background and purpose of the research to the participants. Furthermore, the researcher created a positive interview environment before asking the participants to share their perspectives regarding the implementation of HRM functions, its perceived importance and limitations or barriers to effective HRM implementation within SMCs. Note-taking and a digital voice recorder were used to capture the interview proceedings. The use of this method was informed by the need to ensure trustworthiness and reliability of the data. This study thus made sure to establish trustworthiness in terms of credibility, authenticity, transferability, dependability and confirmability.

\section{Ethical consideration}

Ethical considerations focus on ensuring that the researcher adhered to ethical principles and that codes of ethics are not compromised during the study to protect the participants from any harmful practices (Garriga \& Mele, 2004). Ethical clearance and approval were obtained from the research institution and the organisations where the interviews were conducted (Ethical clearance number: 2017_HRM_006). Permission was obtained from the owners or managers of the relevant SMCs within the industrial area to conduct the research. It was ensured that the ethics procedures of the institution were followed at all times. Participants were provided with an inform consent form clearly stating the purpose of the qualitative study. They were assured of the rightness of their privacy, for example, the identity of the participants was kept anonymous, all the data were handled confidentially and participation was voluntary. Also, participants signed the consent form to grant permission to partake in the study (Welman, Kruger, \& Mitchell, 2005).

\section{Findings and discussion}

The section presents and discusses the research findings of the study in terms of phenomenological qualitative analysis. Data analysis of the interview data yielded four themes relating to the implementation of HRM functions within SMCs. The following themes were identified using Tesch's (1990) method of content analysis: (1) explanation of the implementation of HRM functions, (2) perceived importance of the HRM functions implemented in SMCs, (3) perceived limitations or barriers to effective HRM implementation in SMCs and (4) recommendations for improving HRM practices.

The following section outlines the above-mentioned themes.

\section{Theme 1: Implementation of human resource management functions}

Table 3 shows that 12 subthemes emerged from Question 1 (Regarding the implementation of HRM functions within SMCs, which HRM functions are most commonly implemented within SMCs?). The subthemes related to strategic HRM, recruitment, selection, orientation, HR training and development, labour relations, remuneration and benefits, performance management, HR information systems, manual HR administration, limited benefits and no performance bonuses.

The findings revealed that of the eight SMCs interviewed, participants confirmed that SMCs implemented informal HR practices such as strategic HRM, recruitment, selection, orientation, training and development, labour relations, performance management, and remuneration and benefits. Five participants confirmed that SMCs used manual HR administration. Human resource management functions such as competitive remuneration and benefits, talent management, organisational development, measuring HR success and human resource information systems (HRIS) were not implemented within the sampled SMCs. Human resource information systems was not predominant. However, Participant 3 mentioned that internal systems are used to calculate hours, overtime and to pay salaries. Therefore, it seems as if SMCs implement HRM functions; however, it is carried out informally. Based on the interviews, recruitment, orientation, training and development functions were mostly implemented by the rest of the sampled SMCs. Participant 6 emphasised that training and development are implemented; however, there is a lack of collective participation in training arrangements within the business. According to participants 4 and 8 , the business makes a lower profit; however, employees are entitled to a year-end performance bonus. All the eight participants reported that they comply with labour legislation. However, the extent of compliance was not determined. From Table 2, it could be further concluded that not all HRM functions were implemented within SMCs. It is evident that informally some of the HRM functions are implemented. No formal policies and procedures seem to be in place for guiding the implementation and execution of HRM functions.

\section{Theme 2: Perceived importance of the human resource management functions implemented in small manufacturing companies}

Table 3 shows that seven subthemes emerged from Question 2 (i.e. What is the perceived importance of the HRM functions implemented in SMCs?). The subthemes related to recruitment, remuneration and benefits, labour relations, performance management, HR information systems, orientation, and 
TABLE 3: Summary of the core themes about implementation and perceived importance of human resource management functions as well as perceived limitations or barriers to effective human resource management implementation in small manufacturing companies.

Theme Sub-theme Example of quotes

\section{Implementation of HRM functions}

Question 1: $\quad$ Strategic HRM

Regarding the Recruitment

implementation of

HRM functions

within SMCs, which

HRM functions are

most commonly

implemented within

SMCs?

Recruitment

Participant 1: 'We are currently have ... assisting of management with strategic planning'.

Participant 1: 'We are currently have ... sourcing of employees for the organisation. We have four recruitment sources, number one is word of mouth, number two Department of Labour, number three TVET College, even universities is so required that you need somebody at that level'.

Selection

(Participant 7: 'doing the simplest way, we don't interview, like, for instance, here we are producing clothing so we take somebody who said they know the job; we take that person to the machine, eh ... The machine will interview that person. [We] take you to the machine, you do, if you fail bye-bye. If you have got potential, but you don't know the job, we keep you'.

Orientation

Participant 2: 'Eh ... the newly recruit employee and before in terms of our recruitment procedures is after having gone through other steps. The last few steps that you go through are once the incumbent is relevant to the position that you are looking for. Then you wil have the employee inducted and at the end of the day after induction, the employee will then sign the contract and from there he will go into production where he will then receive on-the-job induction and that's it in short'.

HR training and Participant 8: 'Staff training the only staff training that we have is probably ... mostly in the production department where they would development eh ... identified a potential eehh employees starting from casuals when they hire casuals, and then they identify there is a potential in this particular casual they will train them in-house mostly for eheh production department so we train people in-house for base assembling, mattress assembling and tapping so that gives us eh ... the two sets of staff here, do not come here explain the staff but they will train in-house, eh ... So, we are like a training Centre as well to the community'.

Labour relations Participant 5: 'Eh administration part of the company, eh okay eh administration of leave okay all type of leave, your family responsibility leave, your annual leave, sick leave and other leave okay. Eh is important'.

Remuneration Participant 7: 'Eeehh about the pay is very very easy because of pay we pay according to the bargaining councils; I don't entice if the bargaining council says we must pay R20 an hour that's what we do. Yes "we do pay UIF, provident fund eh workers they have just started to contribute; we have been contributing all this year. We have started last year to contribute we have been paying for them, started to contribute; we have been contributing all this year. We have started last year to contribute
people don't appreciate you see this is somebody's pay slip she earns (Amount) that is $1 \%$ of UIF'.

Performance Participant 4: 'Eh when comes to performance management eh normally during December eh I just give them smallernyana (small) management

HR information Participant 3: 'Eh function is the new system (internal system) that we are trying because we have some shifts ... So, it was difficult for systems us for calculating hours, overtimes; so the new system that we are using now is easier to calculate hours and their overtimes'.

Manual HR Participant 6: 'HR is based in head office, but then we do our own HR, which we send to head office, what we do from here is just administration

Limited benefits

and no

performance

performance
bonuses paperwork'.

Participant 6: 'You don't find this benefits huge benefits that you would like to have. Eh Pension fund I would like it to happen but at the moment no'.

Participant 7: 'No performance bonus this is a very small companies for the past 14 years we have been struggling to be on the ground Participant 7: 'No performance bonus this is a very small companies for the past 14 years we have been struggling to be on the ground
level every day if I have R50 000 that R50 000 within 30 minutes I can spend it with arrears or the money that owe people or buy raw material I don't have incentives'.

\section{Perceived importance of the HRM functions implemented in SMC}

Question 2: What is Recruitment the perceived importance of the

HRM functions

implemented in

SMCs?

Remuneration and

Participant 1: 'Let me start with the sourcing of employees. We have developed eh policies and for sourcing of employees for the organisation; we have a recruitment policy where we have processes on how can we get employees to the company, and it states different sources that we can use'.

Participant 2: 'Can I add on that one? In addition to why we had to come up with this kind of policy was because it's very much important that the people that you recruit should be matched with your job requirements. ... you cannot just recruit anybody that will just come in, and at the end of the day you found that he or she doesn't fit with the position that you have advertised or position that you are looking for; so the very important area of it is to make sure that you have relevant people into the company that match the position that is available'.

Participant 8: 'The leave pays they do help them that when they are away on leave, they can still be able to look after their family when leave is paid when someone is actually taken the annual leave so the implem eh... The system that we are currently using now they are of very much importance in the company'.

Labour relations Participant 5: 'Eh the functions that are very important to small manufacturing companies I would say are your labour relations functions eh; basically looking at your discipline act at workplace okay because discipline remains one of the core functions of each manager and supervisor and eh we want to see an HR function as a custodian of the disciplinary procedure eh that must ensure that there is fairness, consistency and impartiality. Okay then by doing that if we succeed by doing that we would ensure that there is labour peace in the organisation'.

Performance Participant 4: 'The importance ... Eh... about the performance management as I said it, we give them smallonyana (small) bonus at the management [end] of the year okay; that bonus for me is to give them a spirit and just to thank them for all the things we did through the year, so they come again next year just to keep the spirit and maybe that money can play a part on some of the problems they have at their homes during December'.

HR information Participant 3: 'Just to make sure that the payments are up-to-date and every one the rate[s] is [are] going accordingly. Mostly before systems Participant 3: 'Just to make sure that the payments are up-to-date and every one the rate[s] is [are] going accordingly. Mostly before
the recycling ... we were paying people cash so using the system was easier. Paying cash is dangerous. People don't know how to save the recycling ... we were paying people cash so using the system was easier. Paying cash is dangerous. People don't know how to save
[be]cause they get cash on hand [and] they spend it a lot. So, if we are using this system is going through the bank they know how to [be]cause they get cash on hand [and] they spend it a lot.

Orientation Participant 2: 'Once the incumbent is relevant to the position that you are looking for, then you will have the employee inducted and at the end of the day after induction, the employee will then sign the contract and from there he will go into production where he will receive on-the-job induction'.

Training and Participant 7: 'Eh ... yes they are when it comes to training eh ... we will train supervisors. We train a person when they are competent. development will only train supervisors who will do; supervisors are my extension, who will do they will carry my instruction to the production line'.

\section{Perceived limitations or barriers to effective HRM implementation in SMCs}

Question 3: What Ineffective

are the perceived employment

limitations or relationships

barriers to effective

HRM

implementation in

SMCs?

Lack of employee capacity

Limited budget and resources
Participant 2: 'Labour relations issues when it comes to eh ... disputes that you may face with within an organisation, normally you will find that most of the small businesses are not organised in terms of unions and management relationships. It will be a relationship that is directly between the employee and the employer and eh when you have eh misunderstanding people tend to run outside rather than look into exhausting the procedures that are in existence in the organisation'.

Participant 8: 'We find and her ... then we end up having to overload one person with all those duties like when you try to do the system using the cut system and what ... when you try to explain to them how it works. It becomes a challenge so at the end of the day we have using the cut system and what ... when you try to explain to them how it works. It becomes a challenge so at the end of the day we have
to refer to using the traditional system that the company has been using and then the other challenge is also we have got a very small staff and eh for you to implement certain system you might need more manpower to do that and then we are working with very limited staff and eh for you to implement certain system you might need more manpower to do that and then we
staff. We are not more than 15 here, and we try to keep it that way because we are a small company'.

Participant 4: 'Okay eh firstly like actually I do have the limits okay eh. The limit is because of like we are a small organisation, so like the profit that we made is not enough for me to implement huge things but then I am willing to implement them just that at the moment like the profit that we are making is not enough for us to implement those things. The business may collapse ... may collapse. do all the things on my own because our businesses as I said before is too small so like sometimes I cannot hire like maybe an HR or someone who is highly qualified eh [be]cause of the profit that I made'. 
TABLE 3: Summary of the core themes about implementation and perceived importance of human resource management functions as well as perceived limitations or barriers to effective human resource management implementation in small manufacturing companies.

\begin{tabular}{|c|c|c|}
\hline Theme & Sub-theme & Example of quotes \\
\hline & $\begin{array}{l}\text { Inadequate } \\
\text { systems }\end{array}$ & $\begin{array}{l}\text { Participant 6: 'We do not have the system whereby from my side, I apply leave on the system. No, I still use a leave form, then I send to } \\
\text { HR, they there have I want to believe that system (wish to have the system in place)'. }\end{array}$ \\
\hline & $\begin{array}{l}\text { Lack of knowledge } \\
\text { and understanding }\end{array}$ & $\begin{array}{l}\text { Participant } 5: \text { 'One of the barriers like I have explained is eh ... maybe the understanding of your senior management here with regard } \\
\text { to the grasping the idea of human resource functions. Okay, the other barrier will be the owners or the entrepreneurs don't necessarily } \\
\text { see eh ... HR functions as a strategic support to the business itself okay eh the other barrier will be eh if the entrepreneur doesn't see } \\
\text { HR as adding value to the business, it becomes difficult to get the buy-in from that person, and if you don't have buy-in, it is difficult to } \\
\text { implement eh whatever you want to implement'. }\end{array}$ \\
\hline \multicolumn{3}{|c|}{ Recommendations for improving HRM practices } \\
\hline \multirow[t]{4}{*}{$\begin{array}{l}\text { Question 4: What } \\
\text { recommendations } \\
\text { can be formulated } \\
\text { for improving HRM } \\
\text { practices? }\end{array}$} & $\begin{array}{l}\text { No } \\
\text { recommendations }\end{array}$ & $\begin{array}{l}\text { Participant 2: 'At the present moment as we rightfully indicated to you that we are in the process of implementing HR system in this } \\
\text { organisation. We cannot really come up with any suggestion or any recommendation as yet but probably as time goes by once the } \\
\text { system is fully implemented maybe we may think of other ways and means of recommendation that we can come up with to improve } \\
\text { the situation but for now we don't have anything'. }\end{array}$ \\
\hline & $\begin{array}{l}\text { Provide training } \\
\text { and development } \\
\text { opportunities }\end{array}$ & $\begin{array}{l}\text { Participant 3: 'We need to make some courses to teach because some small companies are mostly working with part-time people. The } \\
\text { system is working with part-time because mostly it is the permanent system for permanent people; the part-time one is still a } \\
\text { challenge'. }\end{array}$ \\
\hline & $\begin{array}{l}\text { Create awareness } \\
\text { with regards to the } \\
\text { importance of } \\
\text { HRM functions }\end{array}$ & $\begin{array}{l}\text { Participant 5: 'The recommendation that will see is to get your top management to understand the human resource functions, you } \\
\text { know because if you can't get them on board, then the HR functions will suffer alright, eh ... the other thing is eh when senior } \\
\text { management should see HR functions as part of their strategic planning going forward'. }\end{array}$ \\
\hline & $\begin{array}{l}\text { Adopt anti- } \\
\text { nepotism policy }\end{array}$ & $\begin{array}{l}\text { Participant 8: 'Nna I will recommend small companies should do away from employing people in terms of I don't know whether you } \\
\text { call it eh...Nepotism or what whereby you don't get qualify staff and then eh...you are forced to accept what is there you get what I'm } \\
\text { trying to say, where are people who have been hired here because eh ... their relationship between the owner of the company and } \\
\text { whatever whatever. So, I think small company should look at eh ... employing people with qualifications though I know they sometimes } \\
\text { run away from that because it also comes along with proper salary scale that is also regulated by the law'. }\end{array}$ \\
\hline
\end{tabular}

Source: Mokomane, S.E. (2018). Implementation of human resource management functions in selected small manufacturing companies in the Ga-Rankuwa Industrial Area of Gauteng Province. Unpublished dissertation, University of South Africa, Pretoria.

$\mathrm{HR}$, Human resource; HRM, human resource management; SMCs, small manufacturing companies.

training and development. It is evident from Table 2 that the importance of HRM functions in SMCs includes the following: assisting companies to have successful recruitment and appointments; ensuring that small companies conduct successful job induction, providing correct salary and benefits administration, and motivating and increasing employees' morale level. A transfer of skills through offering training to improve organisational performance is crucial. Participants further emphasised that the perceived importance of HRM functions lies in assisting small companies to comply with relevant legislation, such as Labour Relations Act, Unemployment Insurance Act, Basic Conditions of Employment Act, and Occupational Health and Safety. It can be concluded that the implementation of HRM functions is considered essential to ensure successful operation in SMCs. It seems as if employees might think that having formal policies and procedures about HRM functions will ensure the effectiveness of HRM functions and increase productivity in SMCs.

\section{Theme 3: Perceived limitations or barriers to effective human resource management implementation in small manufacturing companies}

Table 3 shows that five subthemes emerged from Question 3 (i.e. What are the perceived limitations or barriers to effective HRM implementation in SMCs?). The subthemes related to ineffective employment relationships, lack of employee capacity, limited budget and resources, inadequate systems and lack of knowledge and understanding. As shown in Table 3 the following limitations or barriers to the effective implementation of HRM in SMCs were reported: (1) company encountered limited budget, (2) lack of resources and capacity, (3) inadequate systems, (4) a weak relationship between employer and employees (ineffective employment relationships), (5) business instability and lack of knowledge and understanding of HRM functions. It can be concluded that the above-mentioned barriers or limitations negatively affect SMCs to implement all HRM functions within the business and, therefore, negatively influence the performance of the company. Furthermore, the participants reported that they are unable to fulfil all HRM functions owing to limited budget and resources within the business.

\section{Theme 4: Recommendations for improving human resource management practices}

Table 3 shows that five subthemes emerged from Question 4 (i.e. What recommendations can be formulated for improving HRM practices?). The participants indicated the following recommendations for improving HRM practices: provide training and development opportunities; create awareness about the importance of HRM functions; implement hands-on management approach and top management buy-in in terms of managing employees, and adopt an anti-nepotism policy.

\section{Discussion}

This study aimed to investigate the implementation of HRM functions and its perceived importance in SMCs, as well as the limitations or barriers to effective HRM implementation in SMCs. The study found that not all HRM functions were implemented within SMCs because of lack of resources and capacity, lack of knowledge and understanding of senior management regarding HRM functions and limited budgets. It is evident that informally some of the HRM functions were implemented. No formal policies and procedures seem to be in place for guiding the implementation and execution of 
HRM functions, which is also confirmed by a study carried out by Mtshokotshe (2018). The interpretations of the participants regarding the implementation of HRM functions and its perceived importance in SMCs as well as the limitations or barriers to effective HRM implementation in SMCs are similar to those indicated by the research literature (Barret \& Mayson, 2007; Mokomane, 2018; MaldonadoGuzman, Garza-Reyes, Ponzon-Castro \& Kumar, 2017). It was evident from the literature that small businesses are not equipped enough to respond to the environmental changes, which affect the business operations owing to the lack of strategic HRM (Simsek \& Heavy, 2011). Darcy, Hill, McCabe and McGovern (2014) stated that the lack of financial resources impacts negatively small companies to adopt some of the HRM functions, which concur with the findings of this study. Schuler and Jackson (2014) further buttressed that owner or manager buy-in is important because management perceptions can be a barrier to the implementation of HRM functions in the business environment.

More specifically, the study found that HRM functions, such as talent management, organisational development, risk management and measuring HR success, were not implemented in SMCs and not seen as important. Strategic HRM and selection were implemented, but they were not seen as important. Although they are very important HRM functions, it seems as if they were not essential for the survival of SMCs. Human resource information systems and remuneration and benefits were partially implemented, but they were seen as important HRM functions. The participants still considered HRM functions as important in SMCs and every organisation; however, the lack of resources (skills, capital, personnel and knowledge) affects the full implementation of HRM functions in SMCs (Baumann-Pauly, Wickert, Spence, \& Scherer, 2013; Okoye \& Ezejiofor, 2013; Terziovski, 2010). Recruitment, labour relations, performance management, orientation, and training and development were implemented and indicated by the participants as important for SMCs. It seems as if HRM functions were informally implemented. However, the participants feel it is essential that it should be formalised into policies and procedures.

The research findings were presented in two forms. The study discussed the integration of the literature review and the empirical study. From eight SMCs interviewed, the participants confirmed that SMCs implemented informal HR practices, such as strategic HRM, recruitment, selection, orientation, training and development, labour relations, performance management, and remuneration and benefits. Human resource management functions such as competitive remuneration and benefits, talent management, organisational development, measuring HR success and HRIS were found not implemented within the sampled SMCs.

The participants also confirmed that SMCs used manual HR administration. One participant reported that internal systems are used to calculate hours, overtime and to pay salaries. The perceptions of participants regarding the implementation of HRM functions in SMCs support previous studies in the literature. The literature indicated that HRM functions in small companies are inadequately implemented. Malhotra and Temponi (2010), Mokomane (2018), and Zhu and Verstraeten (2013) underscored that small businesses do not usually use HRIS in the business environment. Hussain, Wallace and Cornelius (2007) argued that small companies should learn from larger companies to utilise technology for various HR purposes. Although HR practices in SMCs are performed informally, it is evident that the implementation of HRM functions is considered important to ensure successful operation in SMCs. Albrecht, Bakker, Gruman, Macey and Saks (2015) asserted that HRM functions promote excellent communication and ensure that HRM policies and procedures are implemented. However, the participants might be of the view that having formal policies and procedures about HRM functions will ensure the effectiveness of the function and increase productivity in SMCs. This study found that SMCs encountered limitations or barriers to effective HRM implementation in SMCs. The participants reported that limited budget and a lack of resources negatively affect SMCs to implement all HRM functions within the business. Several studies have also found that limited budget and a lack of resources are the most evident limitations or barriers encountered by the SMCs (Ahmer, 2013; Darcy et al., 2014; Jadhav, Mantha, \& Rane, 2014; Ongori \& Migiro, 2010).

The participants provided recommendations for improving HRM practices in SMCs. The most important recommendations provided by the participants were to provide training and development opportunities, create awareness about the importance of HRM functions, implement hands-on management approach and/or top management buy-in regarding managing employees and adopt the anti-nepotism policy.

The above recommendations signify that all managers or owners and employees should get the appropriate training regarding the implementation of HRM functions. Hands-on management approach and/or top management buy-in will assist managers to recognise employees' input and gain more understanding of HRM functions in their business operations. It is necessary to create awareness regarding the importance of HRM functions to encourage SMCs to implement all HRM functions. Also, it is essential to implement anti-nepotism policy in SMCs to prevent any form of preference about recruitment, salary or promotion of a close relative. The antinepotism policy will encourage healthy relationships in the workplace. Managers or owners play a critical role in ensuring that business operation plans and long-term objectives are achieved. Therefore, the manager needs to have extensive knowledge of HRM (Dezdar \& Ainin, 2011; Yates \& Paquette, 2011). Both employer and employees should create a work environment that encourages engagement and ensures successful business operation (Bakker, Albrecht, \& Leiter, 2011; Brown, 2013). Owoyemi, Oyelere and Elegbede (2011) also emphasised that it is essential for both employees and managers to ensure the successful implementation of HRM functions in small companies. 


\section{Practical implications}

All managers or owners and employees must be aware of all the HRM functions that could enhance the performance and success of their organisation. The results of this study may guide SMCs in terms of which functions are essential to implement for the survival of their business. Although it is understandable that SMCs do not see the need or have the resources to implement HRIS within their organisations, incorporating technology is becoming inevitable as we are entering fourth industrial revolution. (Amaral, Jorge, \& Pecas, 2019). Awareness should be created that even though adopting and implementing HRIS may be costly, the longterm benefit that any organisation will gain from using technology will be far more than the initial cost.

\section{Limitations of the study and recommendations for future research}

The study provided contributions regarding the implementation of HRM functions in SMCs. There were limitations of the empirical study: participants in this study were employees of selected SMCs within the Ga-Rankuwa industrial area (Gauteng province). The research only focused on SMCs in Ga-Rankuwa industrial area and excluded other small companies and SMCs from other provinces and other regions of the Gauteng province. Thus, no generalisations can be made, as the perceptions of participants explored in this study could be representative of only the particular SMCs that were included in the study. However, the participants' responses may still be typical of what employees in South African workplace experience, thereby allowing for the transferability of the study findings (Appleton, 1995; Terre Blanche et al. 2006). Future studies integrating more participants from different sectors and provinces of South Africa might reveal further insights into the implementation of HRM functions and its perceived importance as well as limitations or barriers to effective HRM implementation in SMCs.

\section{Conclusion}

Human resource management functions play a vital role in ensuring that business operations are efficiently met to contribute to the overall objectives of the organisation. Therefore, it is essential to implement interventions to enhance employment relationships and to create an understanding of HRM functions. For instance, it can be recommended that SMCs have quarterly informal lunch breaks together or a team-building or sharing session to build rapport and increase satisfaction with employment relationships. Online cheap or free crash courses on HRM functions, a free training programme by labour department or reading of HR magazines (workforce magazine, HR future and HR magazine) on HRM functions and its importance may be beneficial to the owners of SMCs. This may reduce the limitations or barriers to the business, thereby leading to the effective implementation of HRM functions in SMCs.

Small manufacturing companies implement HRIS on a small scale. However, SMCs can rent services and software from the supplier, unlike purchasing a large, expensive HRIS. Training and development opportunities should be provided to both employees and owners. For instance, on-the-job training and off-the-job training methods can be applied to educate both parties to obtain knowledge and improve the understanding of HRM functions. Owners should support HR presentation within the business to create awareness about the importance of HRM functions in SMCs. This will empower and encourage everyone to implement HRM functions successfully in the business environment. Management should follow a more hands-on approach. Human resource management functions in an organisation can be effectively implemented only if the owners or top management communicate the advantages of HR practice within the business environment. Therefore, the implementation of HRM functions should be a collective teamwork from the top management or owners and employees. Small manufacturing companies need to adopt an anti-nepotism policy. This can be done by involving employees in the process of developing the policy and procedure and communicating the approved policy and procedure to staff members. Also, SMCs need to provide training where required. Based on the recommendations of the participants, the researcher made the following recommendations to improve the implementation of HRM functions in SMCs: participants reported that SMCs implemented informal HR practices. However, SMCs need to formalise some of their HRM functions (such as developing clear policies and procedures in terms of recruitment, selection, training and development and performance management) within the business and ensure that those HRM functions that appear as important must be consistently implemented in SMCs.

\section{Acknowledgements}

This article is published from a masters dissertation completed by Ms Segopotse Mokomane.

\section{Competing interests}

The authors have declared that no competing interests exist.

\section{Authors' contributions}

All authors contributed equally to this work.

\section{Funding information}

This research received no specific grant from any funding agency in the public, commercial or not-for-profit sectors.

\section{Data availability statement}

Data sharing is not applicable to this article as no new data were created or analysed in this study. 


\section{Disclaimer}

The views and opinions expressed in this article are those of the authors and do not necessarily reflect the official policy or positions of any affiliated agency of the authors.

\section{References}

Ahmer, Z. (2013). Adoption of human resource information systems innovation in Pakistani organizations. Journal of Quality and Technology Management, IX(II) 25-50.

Akpan, E.I. (2011). Effective safety and health management policy for improved performance of organisations in Africa. African Journal of Economic and ManagementStudies, 1(2),128-137.https://doi.org/10.1108/20400701011073455

Albrecht, S.L., Bakker, A.B., Gruman, J.A., Macey, W.H., \& Saks, A.M. (2015). Employee engagement, human resource management practices and competitive advantage: An integrated approach. Journal of Organizational Effectiveness: People and Performance, 2(1), 7-35. https://doi.org/10.1108/JOEPP-08-2014-0042

Amaral, A., Jorge, D., \& Pecas, P. (2019). Small medium enterprises and industry 4.0: Current models' ineptitude and the proposal of a methodology to successfully implement industry 4.0 in small medium enterprises. Procedia Manufacturing, 41, 1103-1110. https://doi.org/10.1016/j.promfg.2019.10.039

Appleton, J.V. (1995). Analysing qualitative interview data: Addressing issues of validity and reliability. Journal of Advanced Nursing, 22(1), 278-308. https://doi. org/10.1111/j.1365-2648.1995.tb02653.x

Bailey, J. (2008). First steps in qualitative data analysis: Transcribing. Family Practice, 25(2), 127-131. https://doi.org/10.1093/fampra/cmn003

Baird, M., \& Williamson, S. (2010). Women, work and industrial relations in 2009 Journal of Industrial Relations, 52(3), 355-369. https://doi.org/10.1177/00221 85610365644

Bakker, A.B., Albrecht, S.L., \& Leiter, M.P. (2011). Work engagement: Further reflections on the state of play. European Journal of Work and Organizational Psychology, 20(1), 74-88. https://doi.org/10.1080/1359432X.2010.546711

Bani, M., Bani, A., Pourbagher, M., Taghavi, M., \& Mansourian, M. (2014). Measuring the relationship between equity and intellectual capital. Management Science Letters, 4, 739-742. https://doi.org/10.5267/j.msl.2014.2.015

Barrett, R., \& Mayson, S. (2007). Human resource management in growing small firms. Journal of Small Business and Enterprise Development, 14(2), 370-320. https:// doi.org/10.1108/14626000710746727

Bartram, T. (2005). Small firms, big ideas: The adoption of human resource management in Australian small firms. Asia Pacific Journal of Human Resources, 43(1), 137-154. https://doi.org/10.1177/1038411105050311

Batt, R., \& Banerjee, M. (2012). The scope and trajectory of strategic HR research: Evidence from American and British journals. The International Journal of Human Resource Management, 23(9), 1739-1762. https://doi.org/10.1080/09585192.20 11.610933

Baumann-Pauly, D., Wickert, C., Spence, L.J., \& Scherer, A.G. (2013). Organising corporate social responsibility in small and large firms: Size matters. Journal of Business Ethics, 115, 693-705. https://doi.org/10.1007/s10551-013-1827-7

Benedict, C.I. (2013). Economic recession and investment on human resource information systems (HRIS). Journal of Management Development, 32(4), 404418. https://doi.org/10.1108/02621711311326383

Bhengu, M.B., \& Bussin, M. (2012). The perceived effectiveness of employee share options as a mechanism of talent management in South Africa. Acta Commercii, 12(1), 85-93. https://doi.org/10.4102/ac.v12i1.135

Brod, M., Tesler, L.E., \& Christensen, T.L. (2009). Qualitative research and content validity: Developing best practices based on science and experience. Quality of Life Research, 18(9), 1263-1278. https://doi.org/10.1007/s11136-009-9540-9

Brown, A. (2013). Managing challenges in sustaining business excellence. International Journal of Quality \& Reliability Management, 30(4), 461-475. https://doi. org/10.1108/02656711311308420

Caldwell, C., Truong, D.X., Linh, P.T., \& Tuan, A. (2011). Strategic human resource management as ethical stewardship. Journal of Business Ethics, 98(1), 171-182. https://doi.org/10.1007/s10551-010-0541-y

Ceylan, C. (2013). Commitment-based HR practices, different types of innovation activities and firm innovation performance. The International Journal of Human Resource Management, 24(1), 208-226. https://doi.org/10.1080/09585192.2012. 680601

Chan, S.H., \& Kuok, O.M. (2011). A study of human resources recruitment, selection, and retention issues in the hospitality and tourism industry in Macau. Journal of Human Resources in Hospitality \& Tourism, 10(4), 421-441. https://doi.org/10.1080/ 15332845.2011.588579

Chand, M., \& Katou, A.A. (2007). The impact of HRM practices on organisational performance in the Indian hotel industry. Employee Relations, 29(6), 576-594. https://doi.org/10.1108/01425450710826096

Cho, S., Woods, R.H., Jang, S., \& Erdem, M. (2006). Measuring the impact of human resource management practices on hospitality firms performances. Hospitality Management, 25(2), 262-277. https://doi.org/10.1016/j.ijhm.2005.04.001

Darcy, C., Hill, J., McCabe, T.J., \& McGovern, P. (2014). A consideration of organisational sustainability in the SME context: A resource-based view and composite model. European Journal of Training and Development, 38(5), 398-414. https://doi. org/10.1108/EJTD-10-2013-0108
Davidson, M.C., Timo, N., \& Wang, Y. (2010). How much does labour turnover cost? A case study of Australian four- and five-star hotels, International Journal of Contemporary Hospitality Management, 22(4), 451-466. https://doi.org/10.1108/ Contemporary Hospitalit

De Queiroz, K. (2007). Species concepts and species delimitation. Society of Systematic Biologists, 56(6), 879-886. https://doi.org/10.1080/10635150701701083

Dezdar, S., \& Ainin, S. (2011). The influence of organisational factors on successful ERP implementation. Management Decision, 49(6), 911-926. https://doi.org/10.1108/ 00251741111143603

Dimba, B.A., \& Rugimbana, R. (2013). An assessment of the moderating role of employees' cultural orientations amongst foreign manufacturing multinational companies in Kenya. SA Journal of Human Resource Management, 11(1), 1-11. https://doi.org/10.4102/sajhrm.v11i1.453

Du Plessis, J.V., \& Fouché, M.A. (2006). A practical guide to labour law (6th edn.). Durban: Lexisnexis Butterworths.

Dulebohnn, J.H., \& Johnson, R.D. (2013). Human resource metrics and decision support: A classification framework. Human Resource Management Review, 23(1), 71-83. https://doi.org/10.1016/j.hrmr.2012.06.005

Frick, B., Malo, M.A., Martínez, P.G., \& Schneider, M. (2012). The demand for individual grievance procedures in Germany and Spain: Labour law changes versus business cycle. Estudios de Economía Aplicada, 30(1), 283-310. https://doi.org/10.25115/ cycle. Estudios
eea.v30i1.3389

Garavan, T.N., Carbery, R., \& Rock, A. (2012). Mapping talent development: Definition, scope and architecture. European Journal of Training and Development, 36(1), 5-24. https://doi.org/10.1108/03090591211192601

Garriga, E., \& Mele, D. (2004). Corporate social responsibility theories: Mapping the territory. Journal of Business Ethics, 53(1/2), 51-71. https://doi. org/10.1023/B:BUSI.0000039399.90587.34

Giorgi, A. (2010). Phenomenology and the practice of science. Existential Analysis: Journal of the Society for Existential Analysis, 21(1), 3-22.

Grossman, R.M., \& Salas, E. (2011). The transfer of training: What really matters International Journal of Training and Development, 15(2), 103-120. https://doi. org/10.1111/j.1468-2419.2011.00373.x

Guest, D.E. (2011). Human resource management and performance: Still searching for some answers. Human Resource Management Journal, 21(1), 3-13. https://doi. some answers. Human Resource Manager
org/10.1111/j.1748-8583.2010.00164.x

Haslinda, A. (2009). Evolving terms of human resource management and development. The Journal of International Social Research, 2(9), 180-186.

Hayfield, N., \& Huxley, C. (2015). Insider and outsider perspectives: Reflections on researcher identities in research with lesbian and bisexual women. Qualitative Research in Psychology, 12(2), 91-106. https://doi.org/10.1080/14780887.2014. 918224

Henning, M. (2019). A conceptual approach to increase competitiveness in a typical South African manufacturing SME (Doctoral dissertation). Stellenbosch: Stellenbosch University.

Hussain, Z., Wallace, J., \& Cornelius, N.E. (2007). The use and impact of human resource information systems on human resource management professionals. Information \& Management, 44(1), 74-89. https://doi.org/10.1016/j.im.2006.10.006

Jacobson, W.S., \& Sowa, J.E. (2015). Strategic human capital management in municipa government: An assessment of implementation practices. Public Personne Management, 44(3), 317-339. https://doi.org/10.1177/0091026015591283

Jadhav, J.R., Mantha, S.S., \& Rane, S.B. (2014). Exploring barriers in lean implementation. International Journal of Lean Six Sigma, 5(2), 122-148. https:// doi.org/10.1108/IJLSS-12-2012-0014

Karadag, H. (2015). Financial management challenges in small and medium-sized enterprises: A strategic management approach. Emerging Markets Journal, 5(1), 26-40. https://doi.org/10.5195/EMAJ.2015.67

Karakas, F., \& Manisaligil, A. (2012). Reorienting self-directed learning for the creative digital era. European Journal of Training and Development, 36(7), 712-731. https://doi.org/10.1108/03090591211255557

Kaur, S. (2013). 360 degrees performance appraisal-benefits \& shortcoming. Internationa Journal of Emerging Research in Management \& Technology, 2(6), 83-88.

Keeling, K.A., McGoldrick, P.J., \& Sadhu, H.S. (2013). Staff word-of-mouth (SWOM) and retail employee recruitment. Journal of Retailing, 89(1), 88-104. https://doi. org/10.1016/j.jretai.2012.11.003

Kehoe, R.R., \& Wright, P.M. (2013). The impact of high-performance human resource practices on employees' attitudes and behaviors. Journal of Management, 39(2), 366-391. https://doi.org/10.1177/0149206310365901

King, N., \& Horrocks, C. (2010). Interviews in qualitative research. London: Sage.

Kotter, John P. 2014. Accelerate: Building strategic agility for a faster-moving world. In American Society for Training \& Development (pp. 1-75). Harvard: Harvard Business Review Press, Boston.

Krishnan, T.N., \& Scullion, H. (2017). Talent management and dynamic view of talent in small and medium enterprises. Human Resource Management Review, 27(3), 431-441. https://doi.org/10.1016/j.hrmr.2016.10.003

Kumari, N. (2012). A study of the recruitment and selection process: SMC global. Industrial Engineering Letters, 2(1), 34-43.

Lengnick-Hall, M.L., Lengnick-Hall, C.A., \& Rigsbee, C.M. (2013). Strategic human resource management and supply chain orientation. Human Resource Management Review, 23(4), 366-377. https://doi.org/10.1016/j.hrmr.2012.07.002

Louw-Potgieter, J. (2012). Evaluating human resource interventions. SA Journal of Human Resource Management, 10(3), 1-6. https://doi.org/10.4102/sajhrm. v10i3.420 
Lukka, K., \& Modell, S. (2010). Validation in interpretive management accounting research. Accounting, Organisations and Society, 35(4), 462-477. https://doi. research. Accounting, Organisatio
org/10.1016/j.aos.2009.10.004

Maldonado-Guzman, G., Garza-Reyes, J.A., Pinzon-Castro, S.Y., \& Kumar, V. (2017). Barriers to innovation in service SMEs: Evidence from Mexico. Industria Management \& Data Systems, 117(8), 1669-1686. https://doi.org/10.1108/ IMDS-08-2016-0339

Malhotra, R., \& Temponi, C. (2010). Critical decisions for ERP integration: Small business issues. International Journal of Information Management, 30(1), 28-37. https://doi.org/10.1016/j.ijinfomgt.2009.03.001

Mannay, D. (2010). Making the familiar strange: Can visual research methods render the familiar setting more perceptible?. Qualitative Research, 10(1), 91-111. https://doi.org/10.1177/1468794109348684

Martin, P., \& Barnard, A. (2013). The experience of women in male-dominated occupations: A constructivist grounded theory inquiry. SA Journal of Industria Psychology, 39(2), 1-12. https://doi.org/10.4102/sajip.v39i2.1099

Mercer, J. (2007). The challenges of insider research in educational institutions: Wielding a double-edged sword and resolving delicate dilemmas. Oxford Review of Education, 33(1), 1-17. https://doi.org/10.1080/03054980601094651

Meyer, M., Roodt, G., \& Robbins, M. (2011). Human resources risk management: Governing people risks for improved performance. SA Journal of Human Resource, 9(1), 1-12. https://doi.org/10.4102/sajhrm.v9i1.366

Mokomane, S.E. (2018). Implementation of human resource management functions in selected small manufacturing companies in the Ga-Rankuwa Industrial Area of Gauteng Province. Unpublished dissertation, University of South Africa, Pretoria.

Mtshokotshe, Z. (2018). The implementation of human resources management strategy within restaurants in East London. South Africa. African Journal of Hospitality, Tourism and Leisure, 7(3), 2223-2814.

Nel, P.S. (2001). Human resources management. In L. Rose-Innes (Ed.), Training and development of employees and career management at organisational level (pp. 466-535). Cape Town: Oxford University Press Southern Africa.

Nielsen, M.W. (2015). Limits to meritocracy? Gender in academic recruitment and promotion processes. Science and Public Policy, 43(3), 1-14.

Nolan, C.T., \& Garavan, T.N. (2016). Human resource development in SMEs: A systematic review of the literature. International Journal of Management Reviews, 18(1), 85-107. https://doi.org/10.1111/ijmr.12062

Ogunyomi, P., \& Bruning, N.S. (2016). Human resource management and organisational performance of small and medium enterprises (SMEs) in Nigeria. The International Journal of Human Resource Management, 27(6), 612-634. https://doi.org/10.108 $0 / 09585192.2015 .1033640$

Okoye, P.V., \& Ezejiofor, R.A. (2013). The effect of human resources development on organizational productivity. International Journal of Academic Research in Business and Social Sciences, 3(10), 250-268. https://doi.org/10.6007/IJARBSS/v3-i10/295

Oliver, C. (2012). Critical realist grounded theory: A new approach for social work research. British Journal of Social Work, 42(2), 371-387. https://doi.org/10.1093/ bjsw/bcr064

Olson, D.L., \& Staley, J. (2012). Case study of open-source enterprise resource planning implementation in a small business. Enterprise Information Systems, 6(1), 79-94. https://doi.org/10.1080/17517575.2011.566697

Ongori, H., \& Migiro, S.O. (2010). Information and communication technologies adoption in SMEs: Literature review. Journal of Chinese Entrepreneurship, 2(1), adoption in SMEs: Literature review. Journal of Chines
93-104. https://doi.org/10.1108/17561391011019041

Owoyemi, O.A., Oyelere, M., \& Elegbede, T. (2011). Enhancing employees' commitment to organisation through training. International Journal of Business and Management, 6(7), 280-286. https://doi.org/10.5539/ijbm.v6n7p280

Pajo, K., Coetzer, A., \& Guenole, N. (2010). Formal development opportunities and withdrawal behaviors by employees in small and medium-sized enterprises. Journal of Small Business Management, 48(3), 281-301. https://doi.org/10.1111/ j.1540-627X.2010.00295.x

Peredaryenko, M.S., \& Krauss, S.E. (2013). Calibrating the human instrument: Understanding the interviewing experience of novice qualitative researchers. The Qualitative Report, 18(43), 1-17.

Prajapati, P. (2018). Small company and it exemptions under Companies Act. 2013. Retrieved from https://www.legalwiz.in.

Przytuła, S. (2013). Compensating expatriates in polish subsidiaries: Pilot research findings. Argumenta Oeconomica, 1(30), 150-172.

Psychogios, A., Szamosi, L.T., Prouska, R., \& Brewster, C. (2016). A three-fold framework for understanding HRM practices in South-Eastern European SMEs. Employee Relations, 38(3), 310-331. https://doi.org/10.1108/ER-07-2014-0078
SABPP. (2013). National HR standards, Johannesburg: South African Busines People Practices.

Schalk, R., Timmerman, V., \& Van den Heuvel, S. (2013). How strategic considerations influence decision making on e-HRM applications. Human Resource Management Review, 23(1), 84-92. https://doi.org/10.1016/j.hrmr.2012.06.008

Schuler, R., \& Jackson, S.E. (2014). Human resource management and organisational effectiveness: Yesterday and today. Journal of Organizational Effectiveness: People and Performance, 1(1), 35-55. https://doi.org/10.1108/JOEPP-01-2014-0003

Schultz, H.B. (2001). Human resources management. In L. Rose-Innes (Ed.), Induction and staffing decisions (pp. 259-275). Cape Town: Oxford University Press Southern Africa.

Sheehan, M. (2014). Human resource management and performance: Evidence from small and medium-sized firms. International Small Business Journal, 32(5), 545-570. https://doi.org/10.1177/0266242612465454

Shen, J., Chanda, A., D'Netto, B., \& Monga, M. (2009). Managing diversity through human resource management: An international perspective and conceptual framework. The International Journal of Human Resource Management, 20(2), 235-251. https://doi.org/10.1080/09585190802670516

Sikora, D.M., \& Ferris, G.R. (2014). Strategic human resource practice implementation: The critical role of line management. Human Resource Management Review, 24(3), 271-281. https://doi.org/10.1016/j.hrmr.2014.03.008

Simsek, Z., \& Heavy, C. (2011). The mediating role of knowledge-based capital for corporate entrepreneurship effects on performance: A study of small to mediumcorporate entrepreneurship effects on performance: A study of small to medium-
sized firms. Strategic Entrepreneurship Journal, 5(1), 81-100. https://doi. sized firms. Strategic
org $/ 10.1002 /$ sej.108

Sloan, A., \& Bowe, B. (2014). Phenomenology and hermeneutic phenomenology: The philosophy, the methodologies, and using hermeneutic phenomenology to philosophy, the methodologies, and using hermeneutic phenomenology to
investigate lecturers' experiences of curriculum design. Quality \& Quantity, 48(3), 1291-1303. https://doi.org/10.1007/s11135-013-9835-3

Terre Blanche, M., Durrheim, K., \& Painter, D. (2006). Research in practice: Applied methods for the social sciences, Cape Town : UCT Press.

Terziovski, M. (2010). Innovation practice and its performance implications in small and medium enterprises (SMEs) in the manufacturing sector: A resource-based view. Strategic Management Journal, 31(8), 892-902. https://doi.org/10.1002/ smj.841

Tesch, R. (1990). Qualitative analysis types and software. New York, NY: Falmer Press.

Tomé, E. (2011). Human resource development in the knowledge based and services driven economy. Journal of European Industrial Training, 35(6), 524-539. https:// doi.org/10.1108/03090591111150077

Totka, M. (2013). How a small business can use big data. Small Business Operations. Retrieved from http://smallbiztrends.com/2013/05/small-business-can-use-bigdata.html.

Tuffrey-Wijne, I., \& Butler, G. (2009). Co-researching with people with learning disabilities: An experience of involvement in qualitative data analysis. Journal compilation, 13(2), 174-184. https://doi.org/10.1111/j.1369-7625.2009.00576.x

Turner, N., Swart, J., \& Maylor, H. (2013). Mechanisms for managing ambidexterity: A review and research agenda. International Journal of Management Reviews, A review and research agenda. International Journal of Managem

Vaismoradi, M., Turunen, H., \& Bondas, T. (2013). Content analysis and thematic analysis: Implications for conducting a qualitative descriptive study. Nursing and Health Sciences, 15(3), 398-405. https://doi.org/10.1111/nhs.12048

Welman, J.C., Kruger, S.J., \& Mitchell, B.C. (2005). Research methodology (3rd edn.). Cape Town: Oxford University Press Southern Africa.

$\mathrm{Wu}$, J.J. (2014). High performance human resource management and enterprise performance: Mediating role of strategy implementation capability. Manager's Journal, 1059(15), 131.

Yadav, R.K., \& Dabhade, N. (2013). Performance management system in Maharatna companies (a leading public sector undertaking) of India: A case study of B.H.E.L., Bhopal (M.P.). International Letters of Social and Humanistic Sciences, 4, 49-69. https://doi.org/10.18052/www.scipress.com/ILSHS.4.49

Yadav, R.K., \& Dabhade, N. (2014). Human resource planning and audit: A case study of HEG limited. International Letters of Social and Humanistic Sciences, 5, 44-62. https://doi.org/10.18052/www.scipress.com/ILSHS.16.44

Yates, D., \& Paquette, S. (2011). Emergency knowledge management and social media technologies: A case study. International Journal of Information Management, 31(1), 6-13. https://doi.org/10.1016/j.ijinfomgt.2010.10.001

Zhu, Y., \& Verstraeten, M. (2013). Human resource management practices with Vietnamese characteristics: A study of managers' responses. Asia Pacific Journal of HumanResources, 51(1),152-174.https://doi.org/10.1111/j.1744-7941.2012.00057.x 